\title{
Genetyczne aspekty farmakokinetyki i farmakodynamiki klopidogrelu
}

\section{Genetic aspects of clopidogrel pharmacokinetics and pharmacodynamics}

\author{
Ewa Laskowska ${ }^{1}$, Aldona Kubica ${ }^{2}$, Jacek Kubica ${ }^{1}$ \\ ${ }^{1}$ Katedra Kardiologii i Chorób Wewnętrznych Collegium Medicum im. Ludwika Rydygiera w Bydgoszczy, \\ Uniwersytet Mikołaja Kopernika w Toruniu \\ ${ }^{2}$ Katedra i Zakład Promocji Zdrowia Collegium Medicum im. im. Ludwika Rydygiera w Bydgoszczy, \\ Uniwersytet Mikołaja Kopernika w Toruniu
}

\section{Streszczenie}

Klopidogrel to jeden z leków stosowanych w leczeniu pacjentów z ostrymi zespołami wieńcowymi. Jest on metabolizowany do aktywnego metabolitu, który jest nieodwracalnym antagonistą płytkowego receptora P2Y ${ }_{12}$ zależnego od adenozynodifosforanu. Odpowiedź farmakokinetyczna i farmakodynamiczna na klopidogrel jest osobniczo zmienna. W pracy przedstawiono przegląd badań służących ocenie związku czynników genetycznych ze skutecznością kliniczną klopidogrelu.

Słowa kluczowe: klopidogrel, agregacja płytek krwi, CYP2C19 polimorfizm, ABCB1 polimorfizm

(Folia Cardiologica 2015; 10, 4: 275-282)

\section{Wstęp}

Klopidogrel jest doustnym prolekiem, pochodną tienopirydyny, hamującym agregację płytek krwi zależną od adenozynodifosforanu (ADP, adenosine diphosphate) [1]. Wyniki wielu badań klinicznych wskazują na to, że 5-10\% pacjentów nie odpowiada na terapię tym lekiem (ang. non-responders), natomiast u 20-40\% pacjentów obserwuje się jego niepełne działanie przeciwpłytkowe [2-6].

Po raz pierwszy osobniczą zmienność odpowiedzi na klopidogrel opisano w 2002 roku [7]. Zastosowano cytometrię przepływową i oceniano stopień wiązania fibrynogenu do płytek krwi w zależności od stężenia ADP [7]. Oporność na klopidogrel (CR, clopidogrel resistance) zdefiniowano jako bezwzględną różnicę między początkową agregacją płytek (\%) i agregacją płytek po podaniu leku (\%) poniżej $10 \%$ [8]. Zahamowanie płytek krwi powyżej 30\% przyjęto za prawidłową reakcję na klopidogrel, natomiast wartości między $10 \%$ a 30\% uznano za niewystarczającą odpowiedź na lek [2]. Ta definicja, zaproponowana przez Gurbela i wsp. [8], nie jest jednak optymalnym wskaźnikiem efektywności leczenia, ponieważ nie pozwala zidentyfikować_pacjentów obciążonych podwyższonym ryzykiem zdarzeń sercowo-naczyniowych z powodu znacznych międzyosobniczych różnic w początkowej reaktywności płytek krwi przed podaniem leku przeciwpłytkowego [9].

Na podstawie analizy wyników wielu badań wypracowano i opublikowano wspólne stanowisko, zgodnie z którym zaproponowano stosowanie określenia „wysoka reaktywność płytek krwi podczas leczenia" (HTPR, high on-treatment platelet reactivity) [9]. Zalecono podawanie bezwzględnej wartości reaktywności płytek krwi podczas leczenia, podając punkty odcięcia wartości agregacji płytek krwi w odniesieniu do różnych metod pomiaru [9]. Wysoka reaktywność płytek krwi

Adres do korespondencji: lek. Ewa Laskowska, Klinika Kardiologii, Szpital Uniwersytecki nr 1 im dr. A. Jurasza, ul. Marii Skłodowskiej-Curie 9 , 85-094 Bydgoszcz, e-mail: laskowskaewa1@gmail.com 
podczas leczenia jest związana ze zwiększonym ryzykiem poważnych niepożądanych zdarzeń sercowo-naczyniowych (MACE, major adverse cardiac events) [10].

Międzyosobnicza zmienność odpowiedzi na klopidogrel ma charakter polietiologiczny [11]. Wśród uwarunkowań klinicznych oporności na ten lek wymienia się między innymi: nieregularne przyjmowanie go, otyłość, cukrzyce, insulinooporność, stan zapalny, niewydolność nerek, poziom początkowej aktywacji płytek, interakcję z innymi lekami, czynniki genetyczne [11-15].

Celem tego systematycznego przeglądu piśmiennictwa jest podsumowanie dostępnej wiedzy dotyczącej wpływu czynników genetycznych na antyagregacyjne działanie klopidogrelu oceniane na podstawie klinicznych wykładników skuteczności oraz bezpieczeństwa zastosowanej terapii oraz badania agregacji płytek krwi. Analizowano piśmiennictwo opublikowane od 1 stycznia 2002 roku do 31 grudnia 2014 roku. Przeglądu dokonano w bazach danych PubMed, CENTRAL, Google Scholar i ClinicalTrials.gov oraz w streszczeniach prac zaprezentowanych na kongresach American College of Cardiology (http://www. acc.org), American Heart Association (http://www.aha.org), European Society of Cardiology (http://www.escardio.org), Transcatheter Cardiovascular Therapeutics (http://www. tctmd.com) i EuroPCR (http://www.europcr.com).

\section{Wchłanianie i metabolizm klopidogrelu}

Klopidogrel jest transportowany z przewodu pokarmowego do krwi w około 50\% i osiąga maksymalne stężenie w osoczu już w 1. godzinie od podania [16]. Regulacja wchłaniania absorpcji leku z przewodu pokarmowego obywa się na zasadzie transportu aktywnego, między innymi z udziałem białka transportowego - glikoproteiny P (P-gp) - kodowanej przez gen ABCB1 [17]. Po przejściu klopidogrelu ze światła jelita do krążenia wrotnego, w 85\% ulega on hydrolizie przez osoczowe esterazy (karboksyloesterazy 1) do nieaktywnej formy karboksylowej [18, 19]. Pozostałe 15\% leku ulega dwuetapowemu przekształceniu w wątrobie, z udziałem enzymów cytochromu P450, do aktywnego metabolitu zawierającego grupę tiolową [20, 21]. W pierwszym etapie klopidogrel jest przekształcany w procesie oksydacji do nieaktywnego metabolicznie 2-okso-klopidogrelu poprzez enzymy cytochromu CYP450, takie jak CYP1A2, CYP2B6 i CYP2C19 [22, 23]. W drugim etapie 2-okso-klopidogrel ulega hydrolizie do niestabilnego, aktywnego metabolitu klopidogrelu (R-130964), zawierającego grupy karboksylową i tiolową [22]. Etap tworzenia tiolowego metabolitu odbywa się z udziałem enzymów cytochromu P450: CYP2B6, CYP2C9, CYP2C19, CYP3A4 [23, 24] (ryc. 1).

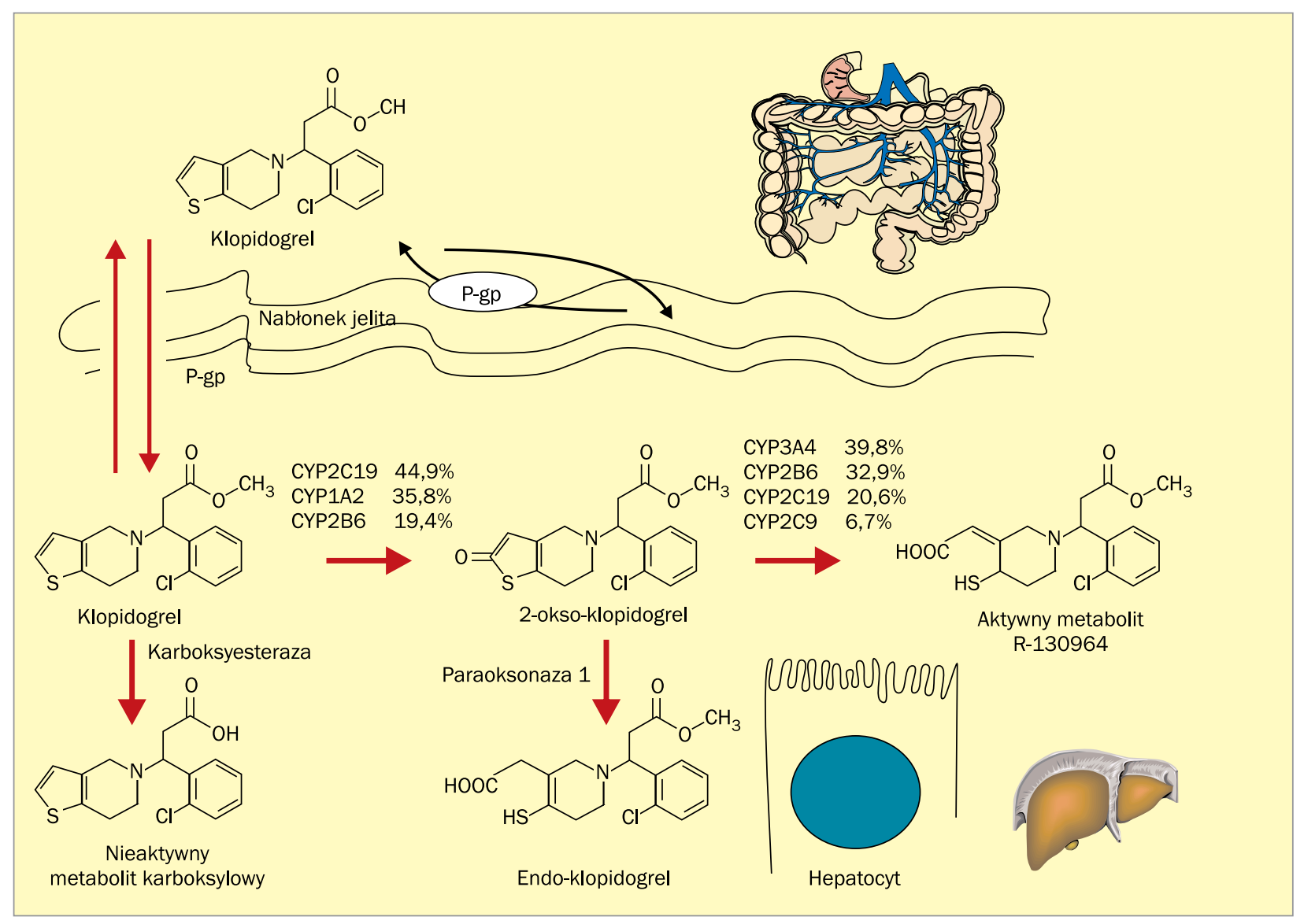

Rycina 1. Metabolizm klopidogrelu (modyfikacja własna na podstawie [23, 24]); P-gp - glikoproteina P 
Biologiczny okres półtrwania aktywnego metabolitu klopidogrelu wynosi około 30 minut $[16,25]$. Wydalanie metabolitów klopidogrelu zachodzi w 41-46\% przez nerki z moczem (w postaci wolnej lub związanej z kwasem glukuronowym - powstają glukuroniany), a w 39-59\% z kałem [26, 27].

\section{Mechanizm działania klopidogrelu}

Aktywny metabolit klopidogrelu hamuje agregację płytek krwi zależną od ADP nieodwracalnie, blokując płytkowy receptor $P 2 Y_{12}$ [1]. Grupa tiolowa tego metabolitu wiąże się z miejscem aktywnym receptora $\mathrm{P}_{2} \mathrm{Y}_{12}$, tworząc mostki dwusiarczkowe z cysteiną (wiązanie kowalencyjne), co powoduje nieodwracalną zmianę konformacji białka receptora i w konsekwencji blokuje dostęp naturalnego agonisty receptora, jakim jest ADP [1]. Z powodu nieodwracalnego wiązania się klopidogrelu z receptorem $P 2 Y_{12}$ okres hamownia funkcji płytek krwi przez lek utrzymuje się zwykle przez 5-10 dni i zależy od sprawności odnawiania populacji trombocytów przez komórki szpiku [28]. W przypadku stosowania dawki $75 \mathrm{mg}$ leku/dobę maksymalny efekt przeciwpłytkowy jest osiągany po 3-7 dniach. Po zastosowaniu pojedynczej dawki nasycającej leku, wynoszącej $600 \mathrm{mg}$, pełny efekt przeciwpłytkowy następuje po 2-3 godzinach od podania [29-31]. Zastosowanie standardowej dawki klopidogrelu powoduje zablokowanie około połowy receptorów P2Y 12 trombocytów [4, 32].

Na podstawie wyników badania ISAR-CHOICE (Intracoronary Stenting and Antithrombotic Regimen: Choose between 3 High Oral doses for Immediate Clopidogrel Effect) stwierdzono, że podanie klopidogrelu w dawce nasycającej $600 \mathrm{mg}$ pozwala na uzyskanie silniejszego zahamowania zależnej od ADP agregacji płytek krwi niż po podaniu $300 \mathrm{mg}$ tego leku. Natomiast dalsze zwiększanie dawki nasycającej klopidogrelu, tj. z 600 mg do 900 mg, nie wiąże się z silniejszym działaniem leku [33].

\section{Czynniki genetyczne wpływające na efekt antyagregacyjny klopidogrelu}

Na farmakokinetykę i farmakodynamikę klopidogrelu modyfikujący wpływ mają czynniki genetyczne, takie jak: polimorfizm genu $A B C B 1$ kodującego białko transportowe P-gp związane z wchłanianiem leku z przewodu pokarmowego, [17, 34], polimorfizm genów kodujących enzymy cytochromu P450 - szczególnie CYP2C19 [34-36], polimorfizm genów kodujących enzym paraoksonaze 1 (PON1) [37], polimorfizm genów kodujących białko receptora $\mathrm{P} 2 \mathrm{Y}_{12}$ [38].

\section{CYP 2 C19}

Cytochrom P450 jest częścią układu wieloczynnościowej monooksydazy (MFO, mixed function oxidases) - zespołu enzymów katalizujących utlenianie substancji endogennych oraz wielu ksenobiotyków [39]. Stwierdzono znaczny polimorfizm genów kodujących enzymy cytochromu P450 (CYP). Wyniki badań wskazują na to, że polimorfizm genu CYP2C19 ma największy związek z metabolizmem klopidogrelu [34-36, 40-42].

Opisano około 25 mutacji genu kodującego enzym CYP2C19 [24], wśród których można wyróżnić warianty prowadzące do utraty bądź zmniejszenia aktywności enzymatycznej (LoF, loss-of-function; utrata funkcji) oraz warianty genu związane ze zwiększoną aktywnością enzymatyczną (GoF, go-of-function; nabycie funkcji) [35, 43]. U nosicieli dwóch dzikich alleli CYP2C19*1/*1 stwierdzono prawidłowy (pośredni) metabolizm klopidogrelu. Do najczęściej występujących w populacji ludzkiej alleli warunkujących utratę aktywności enzymatycznej należą CYP2C19*2 i CYP2C19*3 oraz, znacznie rzadziej występujące, CYP2C19*4 i CYP2C19*5 [24, 44, 45]. Najczęściej występującym w populacji zmutowanym allelem, związanym z wysoką aktywnością enzymatyczną (zwiększoną syntezą aktywnego metabolitu klopidogrelu), jest CYP2C19*17 [40, 41, 46] (tab. 1 [24, 47, 48]). Częstość występowania poszczególnych wariantów genetycznych CYP2C19 pozostaje zmienna w populacji ogólnej i zróżnicowana rasowo $[49,50]$. U około $30 \%$ osób rasy kaukaskiej, 40\% osób rasy czarnej i ponad 55\% Azjatów stwierdzono występowanie nosicielstwa przynajmniej jednego dysfunkcyjnego allelu CYP2C19*2 [50,51]. W populacjach europejskich średnio około $70 \%$ osób jest homozygotami dwóch dzikich alleli CYP2C19*1/*1, około 25\% - heterozygotami CYP2C19*2/*1, natomiast około $2 \%$ - homozygotami CYP2C19*2/*[24, 36]. Allel CYP2C19*17 występuje stosunkowo często w populacjach kaukaskich - u 43\% Polaków, 41\% Niemców, 20\% Francuzów i 18\% Szwedów oraz wśród rasy czarnej - u 18\% Etiopczyków, rzadziej zaś w populacji azjatyckiej - u 4\% Chińczyków [36, 52].

Aktywność metaboliczna enzymu CYP2C19 jest wypadkową konfiguracji alleli występujących u poszczególnych osób (tab. 2) [24, 53].

Tabela 1. Wybrane allele genu CYP2C19 i ich związek z aktywnością enzymu (na podstawie [24, 47, 48])

$\begin{array}{lccc}\begin{array}{l}\text { Allel } \\ \text { cYP2C19 }\end{array} & \begin{array}{c}\text { Różnica sekwencji } \\ \text { nukleotydów w cDNA }\end{array} & \begin{array}{c}\text { Aktywność } \\ \text { enzymu }\end{array} & \begin{array}{c}\text { Występo- } \\ \text { wanie }\end{array} \\ \star 1 & \text { Brak } & \text { Prawidłowa } & 70 \% \\ \star 2 & 681 \mathrm{G} \rightarrow \mathrm{A} & \text { Mniejsza } & 25-55 \% \\ \star 3 & 636 \mathrm{G} \rightarrow \mathrm{A} & \text { Mniejsza } & 1-7 \% \\ \star 4 & 1 \mathrm{~A} \rightarrow \mathrm{G} & \text { Mniejsza } & <1 \% \\ \star 5 & 1297 \mathrm{C} \rightarrow \mathrm{T} & \text { Mniejsza } & <1 \% \\ \star 17 & 991 \mathrm{~A} \rightarrow \mathrm{G} & \text { Większa } & 4-41 \%\end{array}$

CDNA (complementary DNA) - komplementarny DNA; A (adenine) - adenina; C (cytosine) - cytozyna; G (guanine) - guanina; T (thymine) - tymina; 
Tabela 2. Związek polimorfizmów CYP2C19 z metabolizmem klopidogrelu (na podstawie [24])

\begin{tabular}{|c|c|}
\hline Genotyp & Związek z metabolizmem klopidogrelu \\
\hline CYP 2 C $19 * 1 / * 1$ & $\begin{array}{l}\text { Prawidłowy metabolizer - spodziewany prawidłowy metabolizm klopidogrelu i prawidłowa odpowiedź } \\
\text { przeciwpłytkowa na standardową dawkę klopidogrelu }\end{array}$ \\
\hline $\begin{array}{l}\text { CYP2C19*2/*17 } \\
\text { CYP2C19*3/*17 } \\
\text { CYP2C } 19 * 4 / * 17 \\
\text { CYP2C19*5/*17 }\end{array}$ & $\begin{array}{l}\text { Prawidłowy/pośredni metabolizer (LoF/GoF) - spodziewany bardzo nieznacznie spowolniony metabolizm } \\
\text { klopidogrelu i prawidłowa odpowiedź przeciwpłytkowa na standardową dawkę klopidogrelu }\end{array}$ \\
\hline $\begin{array}{l}\text { CYP2C19*1/*2 } \\
\text { CYP2C19*1/*3 } \\
\text { CYP2C19*1/*4 } \\
\text { CYP } 2 \text { C } 19 * 1 / * 5\end{array}$ & $\begin{array}{l}\text { Pośredni metabolizer (*1/LoF) - spodziewany niski metabolizm leku klopidogrel i słaba odpowiedź } \\
\text { przeciwpłytkowa na standardową dawkę klopidogrelu oraz konieczność stosowania większej dawki leku lub } \\
\text { zastosowanie innego inhibitora płytkowego receptora } \mathrm{P}_{2} \mathrm{Y}_{12} \text { (prasugrelu lub tikagreloru) }\end{array}$ \\
\hline $\begin{array}{l}\text { CYP2C19*2/*2 } \\
\text { CYP2C19*2/*3 } \\
\text { CYP2C19*2/*4 } \\
\text { CYP2C19*2/*5 } \\
\text { lub inna konfiguracja } \\
\text { dysfunkcyjnych alleli }\end{array}$ & $\begin{array}{l}\text { Wolny metabolizer (LoF/LoF) - spodziewany jest bardzo niski metabolizm leku klopidogrel (znacznie } \\
\text { zmniejszone stężenie aktywnego metabolitu) i bardzo słaba odpowiedź przeciwpłytkowa na standardową } \\
\text { dawkę leku klopidogrel, oraz konieczność zastosowania wyższej dawki leku lub zastosowanie innego in- } \\
\text { hibitora płytkowego receptora P2Y } \text { Y }_{12} \text { (prasugrel lub tikagrelor) w celu uzyskania oczekiwanego działania } \\
\text { antyagregacyjnego }\end{array}$ \\
\hline CYP2C19*1/*17 & $\begin{array}{l}\text { Szybki metabolizer (*1/GoF) - spodziewany jest wysoki metabolizm leku klopidogrel i wyższa odpowiedź } \\
\text { przeciwpłytkowa na standardową dawkę leku klopidogrel }\end{array}$ \\
\hline CYP2C19*17/*17 & $\begin{array}{l}\text { Ultraszybki metabolizer (GoF/GoF) - spodziewany jest bardzo wysoki metabolizm leku klopidogrel (wysokie } \\
\text { stężenie aktywnego metabolitu) i bardzo wysoka odpowiedź przeciwpłytkowa na standardową dawkę leku } \\
\text { klopidogrel, co może skutkować zwiększonym ryzykiem wystąpienia krwawienia }\end{array}$ \\
\hline
\end{tabular}

\section{CYP2C19*2}

Przeprowadzono wiele badań klinicznych, których wyniki wskazują na związek polimorfizmu pojedynczego nukleotydu (SNP, single-nucleotide polymorphism) CYP2C19*2 z niskim hamowaniem agregacji płytek krwi i wyższym ryzykiem zdarzeń niedokrwiennych u osób leczonych klopidogrelem [36, 46].

W badaniu przeprowadzonym w grupie 259 pacjentów w wieku poniżej 45. roku życia leczonych klopidogrelm po przebytym zawale serca wykazano, że złożony punkt końcowy obejmujący zgon, ponowny zawał serca i konieczność pilnej rewaskularyzacji wystąpił istotnie częściej u nosicieli zmutowanego allelu CYP2C19*2 (*1/*2; *2/*2) niż u homozygot CYP2C19*1/*1 (współczynnik ryzyka [HR, hazard ratio] 3,69; 95-proc. przedział ufności [Cl, confidence interval] 1,69-8,05; $p=0,0005)$ [45]. Częściej występowały także zawał serca (HR 4,54; 95\% Cl 1,64-12,53; $\mathrm{p}=0,001$ ) oraz zakrzepica w stencie (HR 6,02; 95\% Cl 1,81-20,04; $p=0,0009$ ) [45].

W populacji 24852 pacjentów, u których przeprowadzono przezskórną angioplastykę wieńcową z implantacją stentu, ponad 3-krotnie wyższe ryzyko zakrzepicy w stencie w obserwacji trwającej 30 dni zaobserwowano u nosicieli allelu CYP2C19*2 (heterozygoty *1/*2 i homozygoty *2/*2) niż u osób charakteryzujących się prawidłowym metabolizmem klopidogrelu - homozygot CYP2C19*1*1 (1,5\% v. 0,4\%; HR 3,81; 95\% Cl
1,45-10,02; $p=0,007$ ) [54]. Ryzyko zakrzepicy w stencie było najwyższe $(2,1 \%)$ u nosicieli dwóch zmutowanych alleli - homozygot CYP2C19*2/*2 $(p=0,002)$ [54].

W badaniu TRITON TIMI 38 oceniano związek między polimorfizmem genów kodujących CYP2C19 a stężeniem aktywnego metabolitu klopidogrelu, agregacją płytek krwi oraz zdarzeniami sercowo-naczyniowymi [36]. U nosicieli co najmniej jednego allelu związanego z utratą funkcji enzymatycznej CYP2C19*2 (heterozygoty *1/*2 i homozygoty *2/*2) stwierdzono niższe o 32,4\% stężenia aktywnego metabolitu klopidogrelu $(p<0,001)$ niż u osób niebędących nosicielami tej mutacji. Także maksymalna indukowana ADP agregacja płytek krwi była o 9\% mniejsza u nosicieli dysfunkcyjnego allelu ( $p<0,001)$ [36]. W grupie 1477 osób leczonych klopidogrelem z powodu ostrego zespołu wieńcowego $27,2 \%$ było nosicielami allelu zmutowanego CYP2C19*2. U pacjentów tych obserwowano niższe stężenie aktywnego metabolitu klopidogrelu, większą agregacje płytek podczas leczenia oraz wyższe ryzyko wystąpienia zgonu z przyczyn sercowo-naczyniowych, zawału serca i udaru mózgu (pierwszorzędowego złożonego punktu końcowego) niż u pacjentów będących homozygotami CYP2C19*1/*1 (12,1\% v. 8,0\%; HR 1,53; 95\% Cl 1,07-2,19; $p=0,01)$. Stwierdzono także 3-krotnie wyższe ryzyko zakrzepicy w stencie u nosicieli CYP2C19*2 (2,6\% v. 0,8\%; HR 3,09; 95\% Cl 1,19-8,0; $p=0,02)[36]$. 
W opublikowanej w 2010 roku metaanalizie dziesięciu badań klinicznych, obejmującej 11959 osób, nosicielami dysfunkcyjnego allelu CYP2C19*2 było $28 \%(n=3418)$, co - w porównaniu z osobami niebędącymi nosicielami tego allelu - wiązało się z podwyższonym ryzykiem występowania MACE zdefiniowanych jako: zgon z przyczyn sercowo-naczyniowych, zakrzepica w stencie $(9,7 \%$ v. $7,8 \%$; iloraz szans [OR, odds ratio]: 1,29; 95\% Cl 1,12-1,49; $p=0,001$ ). Ponadto obecność wariantu CYP2C19*2 wiązała się ze wzrostem ryzyka zgonu (1,8\% v. 1,0\%; OR 1,79; $95 \% \mathrm{Cl}$ $1,10-2,91 ; p=0,019 ; n=6225)$ i zakrzepicy w stencie (2,9\% v. 0,9\%; OR 3,45; 95\% Cl 2,14-5,57; $p=0,001$; $\mathrm{n}=4905)$. Zwiększone ryzyko wystąpienia MACE obserwowano u heterozygot i homozygot CYP2C19*2, niezależnie od czynników ryzyka sercowo-naczyniowego obecnych wyjściowo [50].

Podobne wyniki uzyskano w innej metaanalizie dotyczącej populacji 9685 osób z chorobą wieńcową [49]. Nosicielstwo jednego zmutowanego allelu CYP2C19, związanego z niską aktywnością enzymatyczną, wykazano u 26,3\% osób, a 2,2\% badanych było nosicielami dwóch dysfunkcyjnych alleli CYP2C19 [49]. Osoby z dwoma dzikimi allelami *1/*1 stanowiły 71,5\% [49]. Zarówno u nosicieli dwóch, jak i jednego allelu związanego z niską aktywnością enzymatyczną CYP2C19 stwierdzono istotnie wyższe ryzyko wystąpienia złożonego punktu końcowego, obejmującego zgon z przyczyn sercowo-naczyniowych, zawał serca oraz udar mózgu, niż u osób z dwoma dzikimi allelami (HR dla dwóch dysfunkcyjnych alleli 1,76; 95\% Cl 1,24-2,5; $p=0,002$; HR dla nosiciela jednego dysfunkcyjnego allelu 1,55; 95\% Cl 1,11-2,27; $p=0,01$ ) [49]. Ryzyko wystąpienia zakrzepicy w stencie u nosicieli jednej kopii dysfunkcyjnego allelu CYP2C19 było ponad 2-krotnie wyższe (HR 2,67; 95\% Cl 1,69-4,22; p < 0,0001), a u nosicieli dwóch zmutowanych alleli - 4-krotnie wyższe (HR 3,97; 95\% Cl 1,75-9,02; $p=0,001$ ) niż u osób będących homozygotami *1/*1 [49].

\section{CYP2C19*17}

Występowanie wariantu genetycznego CYP2C19*17 wiąże się z ultraszybkim metabolizmem klopidogrelu [40, 46]. U osób będących nosicielami mutacji CYP2C19*17 rzadziej niż u osób z allelem CYP2C19*1*1 jest obserwowana HTPR [55]. Obecność CYP2C19*17 może się wiązać z niższym ryzkiem wystąpienia niepożądanych zdarzeń zakrzepowych, lecz jednocześnie wyższe jest ryzyko krwawienia [56].

Jednym z pierwszych badań służących ocenie związku alleli CYP2C19*4 CYP2C19*5 i *6 i CYP2C19*17 z metabolizmem klopidogrelu jest retrospektywna analiza przeprowadzona w grupie 598 osób z zawałem serca bez przetrwałego uniesienia odcinka ST [57]. Oceniano w nim agregację płytek krwi zależną od ADP oraz współczynnik reaktywności płytek krwi w teście fosforylacji białka VASP (PRI VASP, platelet-reactivity index vasodilator-stimulated phosphoprotein) po podaniu $600 \mathrm{mg}$ klopidogrelu [57]. W przypadku polimorfizmów CYP2C19*4, CYP2C19*5 oraz CYP2C19*6 nie wykazano różnic agregacji płytek w porównaniu z osobami niebędącymi nosicielami mutacji [57]. Natomiast u nosicieli zmutowanego genu CYP2C19*17 stwierdzono niższe wartości współczynnika PRI VASP, co sugeruje silniejszą odpowiedź płytek krwi na klopidogrel niż u homozygot CYP2C*1*1 (50\% v. 63\%; $p=0,007)$ [57].

W badaniu przeprowadzonym przez Sibbinga i wsp. [46], w populacji 1524 osób, u których przeprowadzono przezskórną interwencję wieńcową, zbadano związek między indukowaną ADP agregacją płytek a ryzykiem wystąpienia krwawienia, częstością występowania zakrzepicy w stencie oraz nosicielstwem wariantu genetycznego CYP2C19*17. W tym badaniu głównym klinicznym punktem końcowym dotyczącym bezpieczeństwa było wystąpienie krwawienia, a głównym klinicznym punktem końcowym dotyczącym skuteczności - częstość występowania zakrzepicy w stencie. Zarówno u heterozygot (CYP2C19*1/* 17; n = 546), jak i homozygot (CYP2C19*17/*17; $n=76)$ stwierdzono niższe wartości zależnej od ADP agregacji płytek krwi w porównaniu z homozygotami (CYP2C19*1/*1; n = 902; odpowiednio: $p=0,039$ i $p=0,008$ ). Na podstawie analizy wieloczynnikowej stwierdzono, że nosicielstwo allelu CYP2C19*17 jest niezależnym czynnikiem ryzyka występowania krwawień (OR 1,85; 95\% Cl 1,19-2,86; $p=0,006)$. Nie wykazano natomiast związku nosicielstwa CYP2C19*17 z występowaniem zakrzepicy w stencie $(p=0,79)[46]$.

Na podstawie analizy jedenastu badań klinicznych oceniano związek polimorfizmu CYP2C19*17 z występowaniem MACE, krwawień, śmiertelności, zakrzepicy w stencie i HTPR. Osoby z chorobą wieńcową będące nosicielami CYP2C19*17 cechowały się o 16\% niższym ryzykiem MACE niż osoby niebędące nosicielami tej mutacji $(10,0 \%$ v. 11,9\%; OR 0,82; 95\% Cl 0,72-0,94; $p=0,005)$. Stwierdzono także, że nosicieli CYP2C19*17 cechuje wyższe ryzyko krwawień (8,0\% v. 6,5\%; OR 1,25; 95\% Cl 1,07-1,47; $\mathrm{p}=0,006)$. Występowanie HTPR było istotnie rzadsze u nosicieli zmutowanego genu CYP2C19*17 w porównaniu z homozygotami CYP2C19*1*1 (37,9\% v. 50,8\%, OR 0,60; $95 \% \mathrm{Cl} 0,45-0,79 ; p=0,0003)$ [51].

\section{Polimorfizm genetyczny glikoproteiny $\mathrm{P}$}

Odpowiedź płytek krwi na klopidogrel wiąże się także z osobniczą zmiennością sprawności jego transportu ze światła przewodu pokarmowego do układu krążenia. W transporcie aktywnym tego leku uczestniczy P-gp. Glikoproteina ta jest ATP-zależną pompą transportującą, kodowana przez gen $A B C B 1$ zlokalizowany na chromosomie $7[34,58]$. Najlepiej zbadanym polimorfizmem genu 
ABCB1 związanym z farmakokinetyką klopidogrelu oraz jego metabolitów jest zamiana 3435C $\rightarrow$ T [17].

Stwierdzono, że pole powierzchni pod krzywą (AUC, area under curve) stężenia leku w czasie oraz stężenia maksymalne klopidogrelu, a także jego metabolitu są niższe w przypadku genotypu TT niż u homozygoti CC oraz heterozygot CT [17]. Mniej efektywny transport klopidogrelu może powodować zwiększoną reaktywność płytek u osób z genotypem TT w trakcie leczenia antyagregacyjnego [59].

W rejestrze FAST-MI (French Registry of Acute ST-Elevation and Non-ST-Elevation Myocardial Infarction) w populacji ponad 2100 osób liczba homozygot CC stanowiła $25,8 \%$, heterozygot CT $-48,0 \%$, a homozygot TT $-26,2 \%$. Wykazano, że liczba zdarzeń sercowo-naczyniowych w trwającej rok obserwacji jest większa u pacjentów po zawale serca z dwoma wariantami alleli ABCB1 (genotyp TT) niż u osób z dzikim genotypem ABCB1 (15,5\% TT v. 10,7\% CC; HR 1,72; 95\% Cl 1,2-2,47) [34]. Również w subanalizie z badania TRITON-TIMI 38 u osób będących homozygotami (genotyp TT ABCB1) stwierdzono zwiększoną częstość nawrotu zdarzeń niedokrwiennych niż u osób o genotypie CC/ /CT (12,9\% TT v. 7,8\% CT/CC; HR 1,72; 95\% Cl 1,22-2,44; $p=0,002)$ [48].

Wyniki badań klinicznych związanych z polimorfizmem genu $A B C B 1$ nie są jednoznaczne. W metaanalizie opublikowanej przez Singh i wsp. [60] nie stwierdzono związku polimorfizmu genu ABCB1-C3435T z wysokim ryzykiem zdarzeń sercowo-naczyniowych (ryzyko względne [RR, relative risk] 1,13; 95\% $\mathrm{Cl} 0,99-1,29 ; \mathrm{p}=0,06)$ ani występowaniem zakrzepicy w stencie (RR 0,88; $95 \% \mathrm{Cl}$ $0,52-1,47 ; p=0,63)$. Istotnych różnic $w$ tym zakresie nie potwierdzono także w analizie genetycznej badania PLATO (PLATelet inhibition and patient Outcomes) [43].

\section{Paraoksonaza 1}

W metabolizmie klopidogrelu, oprócz enzymów z grupy cytochromu P450, bierze także udział enzym z grupy hydrolaz - PON1 [37]. Wyniki badania Boumana i wsp. [37] wskazują na to, że jeden z polimorfizmów genu kodującego ten enzym (Q192R) wiąże się z efektywniejszym powstawaniem aktywnego metabolitu klopidogrelu. Nosiciele dwóch alleli QQ (PON1 QQ 192) cechują się niższą aktywnością PON1 oraz mniejszym stężeniem aktywnego metabolitu klopidogrelu, a w konsekwencji - słabszym hamowaniem agregacji płytek krwi niż osoby bez mutacji genu kodującego PON1. U homozygot PON1 QQ192, w porównaniu z homozygotami PON1 RR192 i heterozygotami PON1 RQ192, stwierdzono istotnie wyższe ryzyko zakrzepicy w stencie (OR 3,6; 95\% Cl 1,6-7,9; $p=0,003$ ) [37]. Jednak w innych badaniach nie potwierdzono związku polimorfizmu PON1Q192R z efektem antyagregacyjnym klopidogrelu [61-64].

\section{Wnioski}

Przeprowadzony przegląd piśmiennictwa potwierdza istotny wpływ czynników genetycznych na antyagregacyjne działanie klopidogrelu. Mutacje dotyczące genu kodującego enzym CYP2C19, w szczególności warianty *2 oraz *17, wpływają na skuteczność laboratoryjną i kliniczną tego leku. Nie potwierdzono natomiast znaczenia klinicznego innych badanych wariantów genetycznych odpowiedzialnych za wchłanianie i metabolizm klopidogrelu, które mogą być związane z mierzalnymi różnicami aktywności płytek krwi.

\section{Konflikt interesów}

Autorzy nie zgłaszają konfliktu interesów.

\section{Abstract}

Clopidogrel is one of drugs used in patients with acute coronary syndromes. Clopidogrel is metabolized to active metabolite, which is an irreversible platelet $\mathrm{P}_{2} \mathrm{Y}_{12}$ adenosine diphosphate receptor antagonist. The pharmacokinetic and pharmacodynamic response to clopidogrel varies between individuals. The paper presents a systematic review of studies evaluating the association between genetic factors and clinical efficacy of clopidogrel.

Key words: clopidogrel, platelet aggregation, CYP2C19*2 polymorphism, ABCB1 polymorphism

(Folia Cardiologica 2015; 10, 4: 275-282)

\section{Piśmiennictwo}

1. Ding Z., Kim S., Dorsam R. i wsp. Inactivation of the human P2Y12 receptor by thiol reagents requires interaction with both extracellular cysteine residues Cys 17 and Cys 270. Blood 2003; 101: 3908-3914.

2. Muller I., Besta F., Schulz C.I. i wsp. Prevalence of clopidogrel non-responders among patients with stable angina pectoris scheduled for elective coronary stent placement. Thromb. Haemost. 2003; 89: 783-787.
3. Matetzky S., Shenkman B., Guetta V. i wsp. Clopidogrel resistance is associated with increased risk of recurrent atherothrombotic events in patients with acute myocardial infarction. Circulation 2004; 109: 3171-3175.

4. Serebruany V.L., SteinhubI S.R., Berger P.B. i wsp. Variability in platelet responsiveness to clopidogrel among 544 individuals. J. Am. Coll. Cardiol. 2005; 45: 246-251. 
5. O'Donoghue M., Wiviott S.D. Clopidogrel response variability and future therapies: clopidogrel: does one size fit all? Circulation 2006; 114: e600-e606.

6. Sangkuhl K., Klein T.E., Altman R.B. Clopidogrel pathway. Pharmacogenet. Genomics 2010; 20: 463-465.

7. Järemo P., Lindahl T.L., Fransson S.G., Richter A. Individual variations of platelet inhibition after loading doses of clopidogrel. J. Intern. Med. 2002; 252: 233-238.

8. Gurbel P., Blinden K., Hiatt B. i wsp. Clopidogrel for coronary stenting response variability, drug resistance, and the effect of pretreatment platelet reactivity. Circulation 2003; 107: 2908.

9. Bonello L., Tantry U.S., Marcucci R. i wsp. Consensus and future directions on the definition of high on-treatment platelet reactivity to adenosine diphosphate. J. Am. Coll. Cardiol. 2010; 56: 919-933.

10. Cattaneo M. High on-treatment platelet reactivity - definition and measurement. Thromb. Haemost. 2013; 109: 792-798.

11. Geisler T., Schaeffeler E., Dippon J. i wsp. CYP2C19 and nongenetic factors predict poor responsiveness to clopidogrel loading dose after coronary stent implantation. Pharmacogenomics 2008; 9: 1251-1259.

12. Béres B.J., Tóth-Zsámboki E., Vargová K. i wsp. Analysis of platelet alpha-2 adrenergic receptor activity in stable coronary artery disease patients on dual antiplatelet therapy. Thromb. Haemost. 2008; 100 : 829-836.

13. Bhatt D.L. What makes platelets angry: diabetes, fibrinogen, obesity, and impaired response to antiplatelet therapy? J. Am. Coll. Cardiol. 2008; 52: 1060-1061.

14. Moukarbel G.V., Bhatt D.L. Antiplatelet therapy and proton pump inhibition: clinician update. Circulation 2012; 125: 375-380.

15. Frelinger A.L. 3rd, Lee R.D., Mulford D.J. i wsp. A randomized, 2-period, crossover design study to assess the effects of dexlansoprazole, lansoprazole, esomeprazole, and omeprazole on the steady-state pharmacokinetics and pharmacodynamics of clopidogrel in healthy volunteers. J. Am. Coll. Cardiol. 2012; 59: 1304-1311.

16. Hurbin F., Boulenc X., Daskalakis N. i wsp. Clopidogrel pharmacodynamics and pharmacokinetics in the fed and fasted state: a randomized crossover study of healthy men. J. Clin. Pharmacol. 2012; 52: 1506-1515.

17. Taubert D., von Beckerath N., Grimberg G. i wsp. Impact of P-glycoprotein on clopidogrel absorption. Clin. Pharmacol. Ther. 2006; 80: 486-501.

18. Husted S., Emanuelsson H., Heptinstall S. i wsp. Pharmacodynamics, pharmacokinetics, and safety of the oral reversible P2Y12 antagonist AZD6140 with aspirin in patients with atherosclerosis: a double-blind comparison to clopidogrel with aspirin. Eur. Heart J. 2006; 27: 1038-1047.

19. Tang M., Mukundan M., Yang J. i wsp. Antiplatelet agents aspirin and clopidogrel are hydrolyzed by distinct carboxylesterases, and clopidogrel is transesterificated in the presence of ethyl alcohol. J. Pharmacol. Exp. Ther. 2006; 319: 1467-1476.

20. Ma T.K.W., Lam YY., Tan V.P. i wsp. Impact of genetic and acquired alteration in cytochrome P450 system on pharmacologic and clinical response to clopidogrel. Pharmacol. Ther. 2010; 125: 249-259.

21. Pereillo J.M., Maftouh M., Andrieu A. i wsp. Structure and stereochemistry of the active metabolite of clopidogrel. Drug Metab. Dispos. 2002; 30: 1288-1295.

22. Savi P., Zachayus J.L., Delesque-Touchard N. i wsp. The active metabolite of clopidogrel disrupts $\mathrm{P} 2 \mathrm{Y} 12$ receptor oligomers and partitions them out of lipid rafts. Proc. Natl. Acad. Sci. USA 2006; 103: 11 069-11 074.
23. Kazui M., Nishiya Y., Ishizuka T. i wsp. Identification of the human cytochrome P450 enzymes involved in the two oxidative steps inthe bioactivation of clopidogrel to its pharmacologically active metabolite. Drug Metab. Dispos. 2010; 38: 92-99.

24. Kubica A., Kozinski M., Grześk G. i wsp. Genetic determinants of platelet response to clopidogrel. J. Thromb. Thrombolysis 2011: 32: 459-466.

25. Takahashi M., Pang H., Kawabata K. i wsp. Quantitative determination of clopidogrel active metabolite in human plasma by LC-MS/MS. J. Pharm. Biomed. Anal. 2008; 48: 1219-1224.

26. Caplain H., Donat F., Gaud C., Necciari J. Pharmacokinetics of clopidogrel. Semin. Thromb. Hemost. 1999; 25 (supl. 2): 25-28.

27. Lins R., Broekhuysen J., Necciari J., Deroubaix X. Pharmacokinetic profile of 14C-labeled clopidogrel. Semin. Thromb. Hemost. 1999; 25 (supl. 2): 29-33.

28. Quinn M.J., Fitzgerald D.J. Ticlopidine and clopidogrel. Circulation 1999; 100: 1667-1672.

29. Thebault J., Kieffer G., Lowe G. i wsp. Single-dose pharmacodinamics of clopidogrel. Semin. Thromb. Hemost. 1999; 25: 3-8.

30. Kandzari D., Berger P., Kastrati A. i wsp. Influence of treatment duration with a $600 \mathrm{mg}$ dose of clopidogrel before percutaneous coronary revascularization. J. Am. Coll. Cardiol. 2004; 44: 2133-2136.

31. Hochholzer W., Trenk D., Frundi D. i wsp. Time dependence of platelet inhibition after a 600-mg loading dose of clopidogrel in a large, unselected cohort of candidates for percutaneous coronary intervention. Circulation 2005; 111: 2560-2564.

32. Gurbel P.A., Bliden K.P., Hayes K.M. i wsp. The relation of dosing to clopidogrel responsiveness and the incidence of high post-treatment platelet aggregation in patients undergoing coronary stenting. J. Am. Coll. Cardiol. 2005; 45: 1392-1396.

33. von Beckerath N., Taubert D., Pogatsa-Murray G. i wsp. Absorption, metabolization, and antiplatelet effects of 300-, 600-, and 900-mg loading doses of clopidogrel: results of the ISAR-CHOICE (Intracoronary Stenting and Antithrombotic Regimen: Choose Between 3 High Oral Doses for Immediate Clopidogrel Effect) Trial. Circulation 2005; 112: 2946-2950.

34. Simon T., Verstuyft C., Mary-Krause M. i wsp. French Registry of Acute ST-Elevation and Non-ST-Elevation Myocardial Infarction (FAST-MI) Investigators. Genetic determinants of response to clopidogrel and cardiovascular events. N. Engl. J. Med. 2009; 360: 363-375.

35. Hulot J.S., Bura A., Villard E. i wsp. Cytochrome P450 2C19 loss-of-function polymorphism is a major determinant of clopidogrel responsiveness in healthy subjects. Blood 2006; 108: 2244-2247.

36. Mega J.L., Close S.L., Wiviott S.D. i wsp. Cytochrome P-450 polymorphisms and response to clopidogrel. N. Engl. J. Med. 2009; 360: 354-362.

37. Bouman H.J., Schömig E., van Werkum J.W. i wsp. Paraoxonase-1 is a major determinant of clopidogrel efficacy. Nat. Med. 2011; 17: 110-116.

38. Staritz P., Kurz K., Stoll M. i wsp. Platelet reactivity and clopidogrel resistance are associated with the $\mathrm{H} 2$ haplotype of the P2Y12-ADP receptor gene. Int. J. Cardiol. 2009; 133: 341-345.

39. Skrętkowicz J., Rychlik-Sych M. Polimorfizm cytochromu P-450. Farm. Pol. 2008; 64: 61 .

40. Frere C., Cuisset T., Morange P.E. i wsp. Effect of cytochrome p450 polymorphisms on platelet reactivity after treatment with clopidogrel in acute coronary syndrome. Am. J. Cardiol. 2008; 101: 1088-1093.

41. James S., Akerblom A., Cannon C.P. i wsp. Comparison of ticagrelor, the first reversible oral $\mathrm{P} 2 \mathrm{Y}(12)$ receptor antagonist, with clopidogrel 
in patients with acute coronary syndromes: rationale, design, and baseline characteristics of the PLATelet inhibition and patient Outcomes (PLATO) trial. Am. Heart J. 2009; 157: 599-605.

42. Trenk D., Hochholzer W., Fromm M.F. i wsp. Cytochrome P450 2C19 $681 \mathrm{G}>A$ polymorphism and high onclopidogrel platelet reactivity associated with adverse 1-year clinical outcome of elective percutaneous coronary intervention with drug-eluting or bare-metal stents. J. Am. Coll. Cardiol. 2008; 51: 1925-1934.

43. Wallentin L., James S., Storey R.F. i wsp. Effect of CYP2C19 and ABCB1 single nucleotide polymorphisms on outcomes of treatment with ticagrelor versus clopidogrel for acute coronary syndromes: a genetic substudy of the PLATO trial. Lancet 2010; 376: 1320-1328.

44. Storey R.F. Clopidogrel in acute coronary syndrome: to genotype or not? Lancet 2009; 373: 276-278.

45. Collet J.P., Hulot J.S., Pena A. i wsp. Cytochrome P450 2 C19 polymorphism in young patients treated with clopidogrel after myocardial infarction: a cohort study. Lancet 2009; 373: 309-317.

46. Sibbing D., Koch W., Gebhard D. i wsp. Cytochrome 2C19*17 allelic variant, platelet aggregation, bleeding events, and stent thrombosis in clopidogrel-treated patients with coronary stent placement. Circulation 2010; 121: 512-518.

47. Human Cytochrome P450 (CYP) Allele Nomenclature Committee. Dostępne na: http://www.cypalleles.ki.se. Data dostępu: 16.11.2014.

48. Mega J.L., Close S.L., Wiviott S.D. i wsp. Genetic variants in ABCB1 and CYP2C19 and cardiovascular outcomes after treatment with clopidogrel and prasugrel in the TRITON-TIMI 38 trial: a pharmacogenetic analysis. Lancet 2010; 376: 1312-1319.

49. Mega J.L., Simon T., Collet J.P. i wsp. Reduced-function CYP2C19 genotype and risk of adverse clinical outcomes among patients treated with clopidogrel predominantly for PCI: a meta-analysis. JAMA 2010; 304: 1821-1830.

50. Hulot J.S., Collet J.P., Pena A. i wsp. Cardiovascular risk in clopidogrel-treated patients according to cytochrome P450 2C10*2 lossof-function allele or proton pump inhibitor coadministration: a systematic metaanalysis. J. Am. Coll. Cardiol. 2010; 56: 134-114.

51. Li Y., Tang H-L., Hu Y-F., Xie H-G. The gain-of-function variant allele CYP2C19*17: a doubleedged sword between thrombosis and bleeding in clopidogrel-treated patients. J. Thromb. Haemost. 2012; 10: 199-206.

52. Sugimoto K., Uno T., Yamazaki H., Tateishi T. Limited frequency of the CYP2C19*17 allele and its minor role in a Japanese population. Br. J. Clin. Pharmacol. 2008; 65: 437-439.
53. Kubica A., Kasprzak M., Obońska K. i wsp. Impact of CYP2C19 polymorphisms on antiplatelet efficacy of clopidogrel in patients after myocardial infarction. Folia Medica Copernicana 2013; 1: 12-17.

54. Sibbing D., Stegherr J., Latz W. i wsp. Cytochrome P450 2 C19 loss-offunction polymorphism and stent thrombosis following percutaneous coronary intervention. Eur. Heart J. 2009; 30: 916-922.

55. Grosdidier C., Quilici J., Loosveld M. i wsp. Effect of CYP2C19*2 and *17 genetic variants on platelet response to clopidogrel and prasugrel maintenance dose and relation to bleeding complications. Am. J. Cardiol. 2013; 111: 985-990.

56. Tiroch K.A., Sibbing D., Koch W. i wsp. Protective effect of the CYP2C19 *17 polymorphism with increased activation of clopidogrel on cardiovascular events. Am. Heart J. 2010; 160: 506-512.

57. Frére C., Cuisset T., Gaborit B. i wsp. The CYP2C19*17 allele is associated with better platelet response to clopidogrel in patients admitted for non-ST acute coronary syndrome. J. Thromb. Haemost. 2009; 7: 1409-1411.

58. Fojo A., Lebo R., Shimizu N. i wsp. Localization of multidrug resistance-associated DNA sequences to human chromosome 7. Somat. Cell Mol. Genet. 1986; 12: 415-420.

59. Śpiewak M., Małek Ł.A., Kostrzewa G. i wsp. Influence of C3435T multidrug resistance gene-1 (MDR-1) polymorphism on platelet reactivity and prognosis in patients with acute coronary syndromes. Kardiol. Pol. 2009; 67: 827-834.

60. Singh M., Shah T., Adigopula S. i wsp. CYP2C19*2/ABCB1-C3435T polymorphism and risk of cardiovascular events in coronary artery disease patients on clopidogrel: is clinical testing helpful? Indian Heart J. 2012; 64: 341-352.

61. Sibbing D., Koch W., Massberg S. i wsp. No association of paraoxonase-1 Q192R genotypes with platelet response to clopidogrel and risk of stent thrombosis after coronary stenting. Eur. Heart J. 2011; 32: 1605-1613.

62. Simon T., Steg P.G., Becquemont L. i wsp. Effect of paraoxonase-1 polymorphism on clinical outcomes in patients treated with clopidogrel after an acute myocardial infarction. Clin. Pharmacol. Ther. 2011; 90: 561-567.

63. Trenk D., Hochholzer W., Fromm M.F. i wsp. Paraoxonase-1 Q192R polymorphism and antiplatelet effects of clopidogrel in patients undergoing elective coronary stent placement. Circ. Cardiovasc. Genet. 2011; 4: 429-436.

64. Chen D.Y., Wang C.Y., Wen M.S. i wsp. Paraoxonase-1 is not a major determinant of stent thrombosis in a Taiwanese population. PLoS One 2012; 7: e39178. 